University of Nebraska - Lincoln

DigitalCommons@University of Nebraska - Lincoln

$5-24-2019$

\title{
Detection and quantification of residues in sheep exposed to trace levels of dietary zilpaterol $\mathrm{HCl}$
}

\author{
David J. Smith \\ USDA ARS, david.j.smith@ars.usda.gov \\ Weilin L. Shelver \\ USDA ARS, weilin.shelver@usda.gov \\ Shubhashis Chakrabarty \\ USDA ARS \& ORISE Post-Doctoral Fellow \\ Travis W. Hoffman \\ North Dakota State University--Fargo, travis.w.hoffman@ndsu.edu
}

Follow this and additional works at: https://digitalcommons.unl.edu/usdaarsfacpub

Smith, David J.; Shelver, Weilin L.; Chakrabarty, Shubhashis; and Hoffman, Travis W., "Detection and quantification of residues in sheep exposed to trace levels of dietary zilpaterol HCl" (2019). Publications from USDA-ARS / UNL Faculty. 2187.

https://digitalcommons.unl.edu/usdaarsfacpub/2187

This Article is brought to you for free and open access by the U.S. Department of Agriculture: Agricultural Research Service, Lincoln, Nebraska at DigitalCommons@University of Nebraska - Lincoln. It has been accepted for inclusion in Publications from USDA-ARS / UNL Faculty by an authorized administrator of DigitalCommons@University of Nebraska - Lincoln. 


\title{
Detection and quantification of residues in sheep exposed to trace levels of dietary zilpaterol $\mathrm{HCl}$
}

\author{
David J. Smith (10), Weilin L. Shelvera, Shubhashis Chakrabartya,b and Travis W. Hoffman ${ }^{c}$ \\ aUSDA ARS, Edward T. Schafer Agricultural Research Center, Biosciences Research Laboratory, Fargo, ND, USA; ${ }^{\circ}$ ORISE Post-Doctoral Fellow, \\ Oak Ridge, USA; 'Department of Animal Sciences, North Dakota State University, Fargo, ND, USA
}

\begin{abstract}
Study objectives were to determine zilpaterol residues in urine and tissues of sheep fed dietary zilpaterol $\mathrm{HCl}$, at levels commensurate with feed contamination, using common and novel screening and quantitative analytical methods. Sheep $(50.0 \pm 2.7 \mathrm{~kg})$ were offered feed $\left(1.75 \mathrm{~kg} / \mathrm{d}\right.$ ) containing $0.0075(\mathrm{~L}), 0.075(\mathrm{M})$, or $0.75(\mathrm{H}) \mathrm{mg} \mathrm{kg}^{-1}$ of zilpaterol for 12 days and were slaughtered with 0 -day $(\mathrm{L}-0, \mathrm{M}-0, \mathrm{H}-0 ; \mathrm{n}=4$ each) or 3-day $(\mathrm{H}-3 ; \mathrm{n}=4)$ withdrawal periods. Rapid immunochromatographic assays (ICA) consistently detected urinary zilpaterol (LOD = 1.7 $\mathrm{ng} \mathrm{mL} \mathrm{L}^{-1}$ ) in L-0 (54.2\%), M-O (96.0\%), and the $\mathrm{H}-0$ (100\%) treatment groups but only detected zilpaterol in tissues (LOD $2.4 \mathrm{ng} \mathrm{g}^{-1}$ ) from the $\mathrm{H}-0$ group. Advanced MS-based technologies detected zilpaterol in some, but not all, tissues of $\mathrm{M}-0, \mathrm{H}-0, \mathrm{~L}-0$, and $\mathrm{H}-3$ sheep. Analytical techniques commonly used to ensure compliance with show-animal rules, import/export guidelines, and regulatory statutes routinely detected residues in animals exposed to zilpaterol at doses insufficient to elicit growth responses.
\end{abstract}

\section{ARTICLE HISTORY}

Received 5 April 2019

Accepted 24 May 2019

\section{KEYWORDS}

B-agonist; doping; food safety; illegal; residue; zilpaterol

\section{Introduction}

Zilpaterol $\mathrm{HCl}$ is a $\beta$-adrenergic agonist labelled for inclusion in cattle feed to increase the rate of weight gain, improve feed efficiency, and increase carcass leanness during the last 20 to 40 days on feed (Merck 2018). Although specifically labelled for cattle, zilpaterol causes growth and leannessenhancing effects in small ruminants including goats (López-Carlos et al. 2014; Hatefi et al. 2017) and sheep (López-Carlos et al. 2010; Brand et al. 2013; Macías-Cruz et al. 2013). In contrast to ractopamine $\mathrm{HCl}$, another $\beta$-agonist feed additive used in ruminants, the efficacy of zilpaterol in non-ruminant species such as swine, chickens, turkeys, horses, humans, and siluriformes has not been published. Nevertheless, the assumption that zilpaterol affects growth and/or body composition, and may enhance athletic performance or competitive advantage, has caused a multitude of competition organizations to ban zilpaterol completely in animals and humans (ARCI 2018; HLSR 2018; WADA 2018). Additionally, zilpaterol is banned for use in beef and other food-animal species by most countries (Centner et al. 2014) and, consequently, zilpaterol in edible tissues of any species is considered violative by numerous international regulatory agencies.

Several zilpaterol violations have been documented in show, performance, and food animals worldwide (Chung and Waters 2013; Hung et al. 2013; Bergin 2014; CHRB 2014). Assays used to determine violative residues depend upon the enforcement agency and may vary with respect to method sensitivity. For banned substances, including zilpaterol, the presence of any residue, no matter how low the concentration, may result in punitive measures (HLSR, Houston Livestock Show and Rodeo 2018; NWSS 2018). Thus, the sensitivity of a given assay, not the nature of an exposure event (purposeful or accidental), may determine whether a given sample contains violative residues. To illustrate, Smith et al. (2016) demonstrated that sheep exposed to ultra-low levels of dietary ractopamine $(10 \mathrm{ng}$ per $\mathrm{kg}$ body weight (bw) per day; $0.5 \mu \mathrm{g}$ per sheep per day) excreted sporadically detectable urinary 
ractopamine using quantitative LC-MS/MS methods. Sheep dosed with $94 \mathrm{ng} \mathrm{kg}^{-1}$ bw per day $(5 \mu \mathrm{g}$ $\mathrm{d}^{-1}$ ) of ractopamine-excreted urine in which ractopamine residues were typically detected using both qualitative screening and quantitative analytical methods. That is, state-of-the-art detection methods were of sufficient sensitivity to detect exposures to ractopamine hundreds of times less than doses of ractopamine required to elicit growth effects in livestock (i.e., about $5 \mathrm{mg} \mathrm{kg}^{-1}$ of feed). Further, detection of ractopamine in urine, but not tissues, occurred in swine fed complete rations containing 3.8 to $11.2 \mu \mathrm{g} \mathrm{kg}^{-1}$ of diet; the source of ractopamine in the ration was through the inclusion of commercial meat and bone meal (Aroeira et al. 2019).

The detection of sub-therapeutic levels of animal feed additives in non-treated animals has practical consequences. For example, inadvertent $\beta$-agonist contamination of feeds has been claimed (Bergin 2014; CHRB 2014), or documented (Scheidegger 2013; RMTC 2016), in several cases in which $\beta$ agonist residues were measured in animals originally thought to have been illegally treated. Punitive measures for the illegal treatment of food or competitive animals can be severe and legal costs can be significant. To date, few studies have correlated actual animal exposure levels with the practical detection of residues using routinely tested matrices and commonly used screening or determinative analytical methods. For $\beta$-agonist compounds, minimum doses (see discussions by Smith 1998; Smith et al. 2016) are required to elicit clinical or growth promoting effects, so there is no performance or economic incentive to expose animals below such doses. Analytical methods used to enforce policies against therapeutic or growth effects are typically sensitive enough to detect animal exposures well below doses labelled for production purposes.

The objectives of this study were to determine levels of dietary zilpaterol $\mathrm{HCl}$, below which growth effects could be expected, but which might return positive responses by screening and determinative analytical methods. Because the detection of illicit drug residues in practice is based on a variety of screening and confirmatory analytical methods, we measured residues using immunochromatographic rapid screening assays (Shelver and Smith 2018), quantitative ELISA
(Shelver and Smith 2006; Shelver et al. 2010), UPLC-MS/MS, and relatively recent rapid mass spectrometric-based detection methods including atmospheric solid analysis probe (ASAP; Chakrabarty et al. 2018) and electrospray ionization inlet mass spectrometry (ESII-MS; Pagnotti et al. 2012; Fenner et al. 2017). These instrumental methods are typical of the range of established (ELISA; UPLC-MS/MS) and emerging (ASAP, ESII-MS) sensitivities and specificities of assays used by regulatory, import/export, show-animal and animal competition officials.

\section{Materials and methods}

\section{Chemicals}

Absolute ethanol (USP-grade) was purchased from Warner-Graham (Cockeysville, MD). Zilpaterol $\mathrm{HCl}$ was extracted from Zilmax ${ }^{\circledast}$ Type A Medicated Article (4.8\% on ground corncob, surfactant, and binder) and recrystallized in ethanol as described in the supplementary material of Chakrabarty et al. (2018). A chemical purity of at least $98 \%$ was determined by the absence of non-assigned protons and carbons in ${ }^{1} \mathrm{H}$ - and ${ }^{13} \mathrm{C}-\mathrm{NMR}$ spectra of recrystallized zilpaterol. Zilpaterol- $\mathrm{d}_{7}$, used as an internal standard, was purchased from Toronto Research Chemicals (Toronto, Ontario, Canada).

\section{Study overview}

Sheep were fed dietary zilpaterol $\mathrm{HCl}$ once daily for 12 consecutive days at levels of $0,0.0075$ (L), 0.075 $(\mathrm{M})$, and $0.75(\mathrm{H}) \mathrm{mg}$ of zilpaterol per $\mathrm{kg}$ of feed. Sheep receiving the $L(n=4)$ and $M(n=4)$ treatments were slaughtered with a 0 -day withdrawal period. The $\mathrm{H}$ treatment level was fed to two sets of four sheep each, one set was killed with a 0-day withdrawal period $(\mathrm{H}-0)$, and one set killed with a 3-day withdrawal period ( $\mathrm{H}-3)$. All treatments were provided in $1.75 \mathrm{~kg}$ of supplement per day so that the theoretical exposure of individual sheep was equivalent to $0.013,0.13$, and $1.3 \mathrm{mg}$ of zilpaterol $\mathrm{HCl}$ per day for the $\mathrm{L}-0, \mathrm{M}-0$, and $\mathrm{H}-0$ and H-3 treatments, respectively. For comparison, the approved zilpaterol $\mathrm{HCl}$ dosage for cattle is $7.5 \mathrm{mg}$ $\mathrm{kg}^{-1}$ of feed ( $90 \%$ dry matter; Zilmax ${ }^{\circledast}$ label, Merck Animal Health, Madison, NJ) equivalent to a daily exposure of $60 \mathrm{mg}$ per day for a growing beef 
animal eating $8 \mathrm{~kg}$ per day. A low end 'growth' dose for sheep is $0.15 \mathrm{mg} \mathrm{kg}^{-1}$ bw (Estrada-Angulo et al. 2008; Rodea et al. 2016), or roughly $7.5 \mathrm{mg} \mathrm{day}^{-1}$ for a $50 \mathrm{~kg}$ animal. Feed $(1.75 \mathrm{~kg})$ was provided at approximately $0730 \mathrm{~h}$ daily and single, point-intime urine samples were collected from animals on study days $0,2,4,6,8,10$, and 12 for the L-0, M-0, and H-0 sheep and on withdrawal days 1,2 , and 3 for the $\mathrm{H}-3$ sheep. Urine was collected at approximately 0900 on each collection day. Daily urine samples were analysed for zilpaterol by lateral-flow screening assay at collection and by quantitative ELISA, UPLC-MS/MS, and ASAP-MS/MS after freezing. Skeletal muscle, liver, kidney and lung extracts were analysed for zilpaterol $\mathrm{HCl}$ by lateral flow assay, ELISA, UPLC-MS/MS, ASAP$\mathrm{MS} / \mathrm{MS}$, and ESII-MS/MS.

\section{Experimental design}

Treatments were each replicated once during four trials resulting in a total of four animals per treatment. The $\mathrm{H}$ treatment $(0.75 \mathrm{mg}$ zilpaterol $\mathrm{HCl}$ per $\mathrm{kg}$ feed) was comprised of two sets of four sheep each. One set of animals was slaughtered with a 0-day withdrawal period ( $\mathrm{H}-0)$, and the other set was slaughtered after a 3-day withdrawal period $(\mathrm{H}-3)$. Four pens $(3.0 \times 3.4 \mathrm{~m})$ within the Biosciences Research Laboratory barn facility were assigned a zilpaterol treatment level, and a single wether lamb per trial was randomly assigned to treatment. Treatments were not randomized across pens between trials to minimize the probability of across-trial zilpaterol contamination. Two control animals served as donors for urine and tissues, these animals were housed separately, but in the same facility, as the zilpaterol-treated sheep.

\section{Test animals}

A study protocol was approved by the local USDA ARS Institutional Animal Care and Use Committee prior to the purchase of research animals. Wether sheep $(n=18)$ were purchased from the North Dakota State University sheep flock and transported approximately $3 \mathrm{~km}$ to the USDA barn facility. Each sheep was uniquely identified by ear tag at arrival, and all animals were adapted to the barn facility for a minimum of $7 \mathrm{~d}$ prior to the initiation of the study protocol with ad libitum access to alfalfa/grass hay and water. During the adaptation period, sheep were trained to eat through head gates by allowing access to $1.75 \mathrm{~kg}$ of control ration per day. Control ration was pelleted and was composed of soy hulls (25.6\%), salt $(0.6 \%)$, ammonium chloride $(0.6 \%)$, limestone (1.9\%), vitamins $\mathrm{A}, \mathrm{D}$, and $\mathrm{E}(0.01 \%, 0.03 \%$, and $0.06 \%$, respectively), dry molasses $(3.1 \%)$, thiamine $(0.01 \%)$, decox $(0.03 \%)$, and ground corn $(68.0 \%)$. On adaptation days 6 and 7 head gates were closed at approximately $0900 \mathrm{~h}$ and sheep were held until micturition occurred (typically less than $1.5 \mathrm{~h}$ ). Urine was collected into $400 \mathrm{~mL}$ polypropylene beakers as described by Smith et al. (2016).

\section{Feed preparation}

A $1 \mathrm{mg} \mathrm{mL} L^{-1}$ stock solution of zilpaterol $\mathrm{HCl}$ was prepared by dissolving $200 \mathrm{mg}$ of zilpaterol $\mathrm{HCl}$ in absolute ethanol within a $200 \mathrm{~mL}$ volumetric flask. The flask was capped, sealed with Parafilm, and mixed by inversion a minimum of 10 times. Three levels of zilpaterol containing feed were prepared. To prepare feed containing $0.0075 \mathrm{mg}$ of zilpaterol per $\mathrm{kg}$ of feed, $0.675 \mathrm{~mL}$ of the zilpaterol $\mathrm{HCl}$ stock solution was transferred to a $500 \mathrm{~mL}$ volumetric flask containing about $200 \mathrm{~mL}$ of absolute ethanol and the flask was diluted to the mark with absolute ethanol. The contents of the flask were transferred to a no-dead volume plastic spray bottle, and the ethanolic zilpaterol solution was sprayed onto $90 \mathrm{~kg}$ of sheep feed as it mixed within a Davis mixer. After the addition of the entire contents of the spray bottle onto feed (over about a 15-min period), sequential $25 \mathrm{~mL}$ additions of clean ethanol were added to the spray bottle, and the rinses were sprayed onto the feed. Prepared feed was transferred from the Davis mixer and spread onto plastic tarpaulins within a confined, concrete-floored animal facility to allow drying for a minimum of 12 h. After drying, $1.75 \mathrm{~kg}$ aliquots of feed were weighed into labelled plastic zipper bags and stored until use at $-20^{\circ} \mathrm{C}$. Feed containing $0.075 \mathrm{mg} \mathrm{kg}^{-1}$ of zilpaterol $\mathrm{HCl}$ was prepared in the same manner except that $500 \mathrm{~mL}$ of working ethanolic solution was prepared by transferring $6.75 \mathrm{~mL}$ of the zilpaterol $\mathrm{HCl}$ stock solution to a $500 \mathrm{~mL}$ volumetric flask. The contents of 
the working solution were transferred to $90 \mathrm{~kg}$ of feed as described. Two treatments $(\mathrm{H}-0$ and $\mathrm{H}-3)$ were based on a dose of zilpaterol at $0.75 \mathrm{mg} \mathrm{kg}^{-1}$ feed. Therefore, a total of $180 \mathrm{~kg}$ of feed containing $0.75 \mathrm{mg}$ of zilpaterol $\mathrm{HCl}$ per $\mathrm{kg}$ of feed was prepared as described except that $135 \mathrm{~mL}$ of the stock solution was transferred to a $1 \mathrm{~L}$ volumetric flask and diluted to the mark.

\section{Study period}

Two control sheep were maintained throughout the live phase of the study (May through August 2017). During each of the four trials, 12 urine samples were collected from the control sheep for a total of 48 samples per control sheep for the study. The large number of control samples was used to assess the propensity of a newly developed zilpaterol immunochromatographic assay (ICA) for returning false-positive results (Shelver and Smith 2018). Wethers were provided ad libitum access to grass/ alfalfa hay, and water and zilpaterol treatments were provided in $1.75 \mathrm{~kg}$ allotments of test feed at approximately $0730 \mathrm{~h}$ daily (Study days 0 to 11 ) for 12 consecutive days. Feeding and sample collection was essentially identical to that described by Smith et al. (2016) with the exception that pre-dose samples were collected from each sheep prior to the initiation of zilpaterol $\mathrm{HCl}$ exposures. The first post-dosing urine sample was collected on Study Day 0 within an hour or two of zilpaterol exposure. Aliquots of urine were analysed by ICA on-site or were frozen $\left(-20^{\circ} \mathrm{C}\right.$ or less) until chemical analysis. On study Day 12 (withdrawal day 0), feed pans were removed from animals approximately $2 \mathrm{~h}$ prior to euthanasia. Sheep were euthanized using a captive bolt stun gun followed immediately by exsanguination. Sheep slaughtered after a 3-day withdrawal period was provided access to control ration $(1.75 \mathrm{~kg})$ on each of withdrawal days 0,1 , and 2 and were euthanized on withdrawal day 3 , approximately $72 \mathrm{~h}$ after the last exposure to zilpaterol containing feed. At slaughter the semitendinosus muscle, lung, liver, and kidneys were removed, cut into 1 to $2 \mathrm{~cm}^{3}$ pieces, aliquoted, and frozen $\left(-20^{\circ} \mathrm{C}\right.$ or less) until analysis.

\section{Sample analysis}

\section{Immunochromatographic analysis}

At collection, each urine sample was assayed by a zilpaterol-specific ICA which has a $90 \%$ positive zilpaterol detection limit of $1.7 \mathrm{ng} \mathrm{mL}^{-1}$ (Shelver and Smith 2018). Briefly, $160 \mu \mathrm{L}$ aliquots of fresh urine were directly applied to the sample pads of immunochromatographic strips, and a 10-min development time was allowed before analyst interpretation. The presence of zilpaterol was indicated by reduced colour intensity or elimination of the test line. Each test was scored as zilpaterol 'negative' or 'positive' by two independent scorers, blinded with respect to sample identity, and results were autonomously recorded. Test strip viability was controlled with the use of a control line (Shelver and Smith 2018); if the control line was absent on a given test strip, the test was considered invalid and was repeated with another test strip. All daily sample assays were concurrently run with both positive $\left(4 \mathrm{ng} \mathrm{mL}^{-1}\right)$ and negative control urine samples.

\section{Quantitative enzyme-linked immunosorbent assay} Competitive inhibition immunoassays were conducted essentially as described by Shelver and Smith (2006). Briefly, samples or matrix matched standards were added to a zilpaterol-butyrate bovine serum albumin coated 96-well plate and coincubated with zilpaterol antibody. After $90 \mathrm{~min}$, the unreacted reagents were washed off the plates using PBS-Tween, and horseradish peroxidaselabelled anti-mouse IgG was subsequently added. Substrate $\left(3,3^{\prime}, 5,5^{\prime}\right.$-tetramethylbenzidine) was used to generate signal and plates were read at $450 \mathrm{~nm}$. The calibration curve used for urine contained points at $0,0.05,0.1,0.2,0.5,1,2,5,10,20,50$, 100 , and $1000 \mathrm{ng} \mathrm{mL}^{-1}$ while tissue standard curves were comprised of $0,0.2,0.5,1,2,5,10$, and $20 \mathrm{ng}$ of zilpaterol per $\mathrm{mL}$. A four-parameter logistic equation was used to fit the calibration curves, and unknown zilpaterol concentrations were extrapolated from the linear portion of the curves. Limits of detection were defined as the concentration that produced $10 \%$ inhibition of antibody binding while the limits of quantitation were defined as the concentration that produced $20 \%$ of inhibition. 


\section{Quantitative UPLC-MS/MS}

Urinary zilpaterol was extracted in preparation for LC-MS/MS as described by Shelver et al. (2010), but quantification was based on zilpaterol- $\mathrm{d}_{7}$ internal standardization. Briefly, a matrix-matched standard curve containing $0,0.1,0.2,1,2,10,20$, and 100 $\mathrm{ng} \mathrm{mL} \mathrm{m}^{-1}$ of zilpaterol and $2 \mathrm{ng} \mathrm{mL} \mathrm{mL}^{-1}$ of zilpaterol- $\mathrm{d}_{7}$ was prepared; the matrix-matched standard curve was extracted as described by Shelver et al. (2010). Sample sets always included pooled control urine, pooled control urine fortified with internal standard (2 ng), pooled control urine fortified with internal standard (2 $\mathrm{ng}$ ) and $4 \mathrm{ng}$ of zilpaterol, and test urine samples fortified with $2 \mathrm{ng}$ of internal standard.

A Waters Acquity Ultra Performance Liquid Chromatograph interfaced with a Waters triple quadrupole mass spectrometer (Waters, Milford, MA) was used for mass spectrometric analysis of urine and tissue samples. Urine samples were prepared for LCMS/MS analysis using the solid phase extraction (SPE) procedure described by Shelver et al. (2010). A minor modification in cone voltage $(40 \mathrm{~V})$ was used, and the collision energies for the transitions of $m / z 244(\mathrm{M}-\mathrm{OH})^{+} \rightarrow 202,244 \rightarrow 185$ and $244 \rightarrow$ 157 were 15, 20 and $30 \mathrm{~V}$, respectively. Tissues were extracted as described by Shelver and Smith (2006) except that a zilpaterol- $\mathrm{d}_{7}$ internal standard was employed. Tissue sample sets included tissue blanks, tissue blanks fortified with an internal standard fortified tissue samples (equivalent to $4 \mathrm{ng} \mathrm{g}^{-1}$ ), and test tissue samples; the internal standard was added to tissues prior to extraction at a level of $2 \mathrm{ng} \mathrm{g}^{-1}$. Tissue extracts were analysed by LC-MS/MS using the conditions described for urine.

The method limits of detection (LOD) and quantification (LOQ) for zilpaterol in urine were set at 0.5 and $1.0 \mathrm{ng} \mathrm{mL}^{-1}$ commensurate with the two lowest matrix-matched zilpaterol standards that were reliably detected and quantified. In order for a sample to qualify as having detectable or quantifiable zilpaterol residues, each sample duplicate had to contain residues above the respective LOD or LOQ. Across urine sample aliquots that had quantifiable $(>1$ $\mathrm{ng} \mathrm{mL}^{-1}$ ) zilpaterol residues, the average within sample relative standard deviation was $5.0 \pm 6.1 \%$ $(\mathrm{n}=109)$. Across 27 sample sets, analytical recovery of zilpaterol fortified into control urine at a 20 ng $\mathrm{mL}^{-1}$ level was $99.1 \pm 10.6 \%$.

\section{Atmospheric solids analysis probe (ASAP)-MS/MS}

Atmospheric pressure mass spectrometric screening and semi-quantitative analysis of tissues were conducted exactly as described by Chakrabarty et al. (2018) using an ASAP probe manufactured by M\&M Mass Spec Consulting, LLC (Hockessin, $\mathrm{DE}$ ). Tissues were prepared by simple acetonitrile extraction followed by centrifugation (Chakrabarty et al. 2018). Mass spectrometric analyses were performed on a Thermo Scientific TSQ Quantum mass spectrometer (Thermo Fisher Scientific, San Jose, CA, USA).

\section{Electrospray ionization inlet (ESII)-MS/MS}

ESII-MS/MS techniques were based on conditions described by Pagnotti et al. (2012) and Fenner et al. (2017). Sample extracts used for analysis were the same as those used for the UPLC-MS/MS analyses, except that the extracted samples were stored frozen $\left(-20^{\circ} \mathrm{C}\right.$ or less) until analysis. Shelver and Smith (2018) previously demonstrated the stability of zilpaterol in biological samples for up to 7 years when stored at $-20{ }^{\circ} \mathrm{C}$. A Thermo Scientific TSQ Quantum mass spectrometer (Thermo Fisher Scientific, San Jose, CA, USA) interfaced with a DIONEX UltiMate 3000 liquid chromatograph (Thermo Fisher Scientific, San Jose, CA, USA) was used for the analyses. The IonMax source from TSQ Quantum was removed and an MSTM, LLC (Newark, DE) multifunctional ionization platform was used for running the samples in ESII mode. For ESII, $3 \mathrm{kV}$ was applied on a metal union linking the tubing from the LC with a fused silica tube $(75 \mu \mathrm{m}$ ID $\times 375 \mu \mathrm{m}$ OD from Waters, USA). The other end of the silica tube was placed $\sim 0.5$ to $1 \mathrm{~mm}$ deep into the heated $\left(350^{\circ} \mathrm{C}\right)$ ion transfer capillary inlet tube of the TSQ Quantum mass spectrometer. A solvent system composed of 1:1 of $5 \%$ methanol in $0.2 \%$ aqueous formic acid and $10 \%$ acetonitrile in $0.2 \%$ methanolic formic acid flowing at $50 \mu \mathrm{L} \mathrm{min}{ }^{-1}$ was used for the analysis of all samples. No column was used to effect chromatographic separation and zilpaterol was eluted in the solvent flow at approximately $0.85 \mathrm{~min}$ after injection. A collision energy of $30 \mathrm{~V}$ was used to fragment the molecular ion $(\mathrm{m} / z 262$ of zilpaterol) to the product ion $\mathrm{m} / z 185$ in the selected reaction monitoring (SRM) mode for quantitation. Zilpaterol standards 
were prepared in blank tissue matrices at $0.1,0.5,1,5$, 10 , and $20 \mathrm{ng} \mathrm{mL}^{-1}$.

\section{Statistical analyses}

Descriptive statistics were calculated using Microsoft Excel 2010 and/or GraphPad Prism version 7.03 for Windows (GraphPad Software, La Jolla California USA). An outlier value in the LC-MS/MS analysis of the $0.0075 \mathrm{mg} \mathrm{kg}^{-1}$ feed treatment urine samples was identified using the Grubb's test $(\alpha=0.001)$ within GraphPad Prism Software.

\section{Results}

\section{Animal exposures}

Table 1 shows target doses, animal weights, final weights, and zilpaterol intakes. Zilpaterol doses consumed by sheep on a mass basis (mg of zilpaterol per day) were $100 \%, 93 \%, 82 \%$, and $86 \%$ of offered doses for the L-0, M-0, H-0 and H-3 treatments, respectively. When doses were calculated on a body weight basis (Table 1) the middle dose was 9.6 times that of the low dose, and about $1 / 10^{\text {th }}$ that of the high dose. Consequently, the actual doses received by each treatment level were separated by an order of magnitude, which was the intent at the inception of the study.

\section{Detection of zilpaterol using an immunochromatographic assay}

Table 2 shows the detection of zilpaterol in sheep urine by a lateral flow immunoassay having a $90 \%$ detection limit of $1.7 \mathrm{ng} \mathrm{mL}^{-1}$ in sheep urine (Shelver and Smith 2018). Of the 96 control samples, two (2.1\%) tested positive by lateral flow; of the 44 total pre-dose urine samples assayed, two tested positive (4.5\%). Overall, of 140 control or pre-dose samples, four tested positive by immunochromatographic assay, corresponding to a $2.9 \%$ false-positive rate. Positive immunochromatographic detections were clearly dose-related with the L- $0, \mathrm{M}-0$, and $\mathrm{H}-0 / \mathrm{H}-3$ zilpaterol treatments returning $54.2 \%, 96 \%$, and $100 \%$ positive screening assays, respectively, during the feeding period. As might be expected, the detection of zilpaterol in urine by the immunochromatographic screening assay decreased sequentially with withdrawal day for the H-3 sheep; that is, $24 \mathrm{~h}$ after withdrawal, zilpaterol was detected in $100 \%$ of the urine samples, but only $50 \%$ and $25 \%$ of the samples

Table 1. Target and actual zilpaterol $\mathrm{HCl}$ exposure levels (means \pm standard deviations).

\begin{tabular}{|c|c|c|c|c|c|c|}
\hline \multirow{2}{*}{$\begin{array}{l}\text { Zilpaterol } \\
\text { level }\end{array}$} & \multirow{2}{*}{$\frac{\text { Offered }}{\text { dose }}$} & \multirow[b]{2}{*}{ Animals } & \multicolumn{2}{|c|}{ Weights } & \multicolumn{2}{|c|}{ Zilpaterol Intake } \\
\hline & & & Starting & Ending & Mass $^{a}$ & Body Wt. $^{\text {b }}$ \\
\hline$m g \mathrm{~kg}^{-1}$ feed & $\overline{m g d^{-1}}$ & $n$ & $k g$ & $\mathrm{~kg}$ & $m g d^{-1}$ & $\mu g \mathrm{~kg}^{-1} \cdot \mathrm{d}^{-1}$ \\
\hline 0.0075 & 0.013 & 4 & $50.3 \pm 3.1$ & $53.4 \pm 3.2$ & $0.013 \pm 0.001$ & $0.25 \pm 0.06$ \\
\hline 0.075 & 0.131 & 4 & $50.7 \pm 2.9$ & $53.6 \pm 2.5$ & $0.122 \pm 0.011$ & $2.4 \pm 0.2$ \\
\hline $0.75-0 \mathrm{D}$ & 1.313 & 4 & $49.3 \pm 1.7$ & $52.6 \pm 1.8$ & $1.08 \pm 0.12$ & $21.1 \pm 1.6$ \\
\hline $0.75-3 \mathrm{D}$ & 1.313 & 4 & $50.1 \pm 3.6$ & $52.8 \pm 3.3$ & $1.13 \pm 0.09$ & $22.0 \pm 0.5$ \\
\hline
\end{tabular}

${ }^{a}$ Actual mass of zilpaterol consumed per day was calculated as the product of the daily dose and the actual amount of zilpaterol containing feed minus orts $\left(\mathrm{mg} \mathrm{kg}{ }^{-1}\right.$ feed ${ }^{*}[\mathrm{~kg}$ offered $-\mathrm{kg}$ orts] $=$ mg consumed $)$.

bilpaterol intake on a body weight basis was calculated using an average wt. calculated from the starting and ending body weights.

Table 2. Detection of zilpaterol residues in sheep urine by immunochromatographic rapid screening assay.

\begin{tabular}{|c|c|c|c|c|c|c|c|c|c|}
\hline \multirow{2}{*}{$\frac{\text { Zilpaterol }}{\text { Treatment }}$} & \multicolumn{2}{|c|}{ Zilpaterol Intake } & \multirow[b]{3}{*}{ Period } & \multicolumn{6}{|c|}{ Rapid Screen Results } \\
\hline & Mass & BW & & $(-)$ & $(+)$ & Total & $(-)$ & $(+)$ & Total \\
\hline$m g \mathrm{~kg}^{-1}$ feed & $\overline{m g d^{-1}}$ & $\overline{\mu g g^{-1} \cdot d^{-1}}$ & & $\bar{n}$ & $\bar{n}$ & $n$ & $\%$ & $\%$ & $\%$ \\
\hline Control & 0 & 0 & & 94 & 2 & 96 & 97.9 & 2.1 & 100 \\
\hline \multirow{2}{*}{0.0075} & 0.013 & 0.25 & Pre-dose $\mathrm{a}^{\mathrm{a}}$ & 11 & 1 & 12 & 91.7 & 8.3 & 100 \\
\hline & & & Dose & 11 & 13 & 24 & 45.8 & 54.2 & 100 \\
\hline \multirow[t]{2}{*}{0.075} & 0.122 & 2.4 & Pre-dose & 11 & 0 & 11 & 100 & 0 & 100 \\
\hline & & & Dose & 1 & 24 & 25 & 4 & 96 & 100 \\
\hline \multirow[t]{2}{*}{$0.75-0 \mathrm{D}$} & 1.08 & 21.1 & Pre-dose & 9 & 1 & 10 & 90 & 10 & 100 \\
\hline & & & Dose & 0 & 26 & 26 & 0 & 100 & 100 \\
\hline \multirow{5}{*}{$0.75-3 \mathrm{D}$} & 1.13 & 22.0 & Pre-dose & 11 & 0 & 11 & 100 & 0 & 100 \\
\hline & & & Dose & 0 & 25 & 25 & 0 & 100 & 100 \\
\hline & & & Withdrawal D1 & 0 & 4 & 4 & 0 & 100 & 100 \\
\hline & & & Withdrawal D2 & 2 & 2 & 4 & 50 & 50 & 100 \\
\hline & & & Withdrawal D3 & 3 & 1 & 4 & 75 & 25 & 100 \\
\hline
\end{tabular}

aPre-dose samples were collected on two days prior to dosing and on the day of dosing (D0) immediately after making zilpaterol containing feed available. Day 0 samples that tested (+) by the immunochromatographic screen and which also tested positive by LC-MS/MS were not included in the pre-dose tally. 

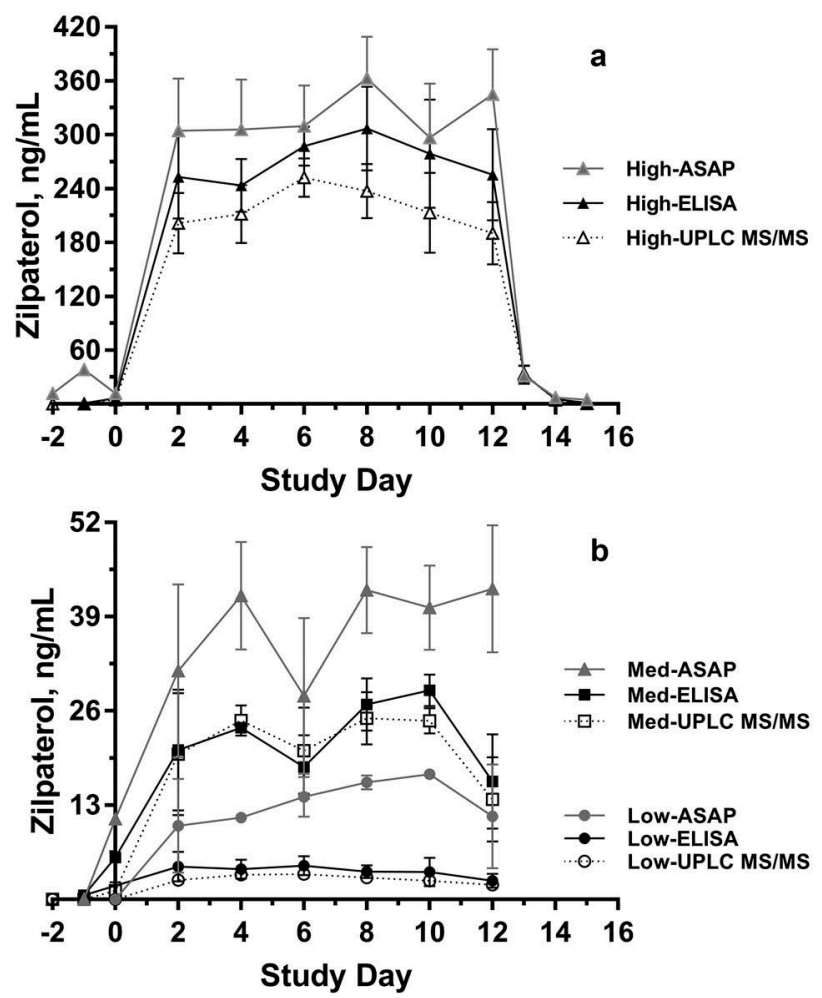

Figure 1. Figure 1. Urinary excretion of zilpaterol as assessed by quantitative ELISA (solid black lines), UPLC-MS/MS (dotted lines), and ASAP-MS (solid grey lines). Panel A, zilpaterol concentrations (ng mL-1) in urine of sheep dosed with $0.75 \mathrm{mg}$ kg-1 of dietary zilpaterol (triangles) and slaughtered with either 0 - $(n=4)$ or 3-day withdrawal periods $(n=4)$. Panel $B$, zilpaterol concentrations in urine of sheep dosed with 0.075 (squares; $n=4$ ) or 0.0075 mg kg-1 (circles; $n=4$ ) of dietary zilpaterol and slaughtered with a 0-d withdrawal period and assayed using ELISA (solid black lines), UPLC-MS/MS (dotted lines), or ASAP-MS (solid grey lines).

at 48 and $72 \mathrm{~h}$ after last zilpaterol exposure tested positive (Table 2).

\section{Quantification of zilpaterol in urine and tissues}

Figures $1 \mathrm{~A}$ and $1 \mathrm{~B}$ show the excretion of zilpaterol in the urine of L-0, M-0 (Figure $1 \mathrm{~B}$ ) and $\mathrm{H}-0$ and $\mathrm{H}-3$ dose animals (Figure 1A) as measured by LCMS/MS and quantitative ELISA. Across dosing days 2 to 12 , corresponding to the period when sheep were actively exposed to dietary zilpaterol, the average urinary zilpaterol concentrations measured by UPLC-MS/MS were $2.8 \pm 1.0,21.4 \pm$ 10.0, and $218 \pm 92 \mathrm{ng} \mathrm{mL} \mathrm{mL}^{-1}$ for the $\mathrm{L}, \mathrm{M}$, and $\mathrm{H}$ doses, respectively. Of note, urinary zilpaterol concentrations accurately reflected the order of magnitude difference in dosing. For the L-0 sheep, all urine samples collected on days 2, 4, 6, 8, 10, and 12 contained ELISA and UPLC-MS/MS quantifiable zilpaterol residues. Urinary zilpaterol as measured by ASAP-MS/MS, a very rapid, semiquantitative mass-spectrometric screening method (Chakrabarty et al. 2018) returned zilpaterol concentrations that were consistent with concentrations returned by ELISA or UPLC-MS/MS, but which required less than a minute total analysis time per sample. It should be noted that data shown in Figure $1 \mathrm{~b}$ reflect the removal of a single datapoint (Day 4 of Trial 4, L-0 treatment) which was deemed to be an outlier by the Grubb's test $\left(72.7\right.$ and $64.9 \mathrm{ng} \mathrm{mL}^{-1}$ by ELISA and UPLCMS/MS, respectively; $\alpha=0.001$ ). The high residue concentrations in this sample almost certainly reflect contamination rather than a physiologic event within the wether because no other samples from that animal or within the treatment group, contained residues greater than $5.1 \mathrm{ng} \mathrm{mL}^{-1}$.

Table 3 shows tissue residues of zilpaterol as assessed by ICA screen (about $10 \mathrm{~min}$ analysis time), ELISA (about $5 \mathrm{~h}$ to analyse 40 samples in 
Table 3. Tissue residues of zilpaterol in sheep receiving feed containing $0.0075,0.075$, and $0.75 \mathrm{mg} \mathrm{kg}^{-1}$ of zilpaterol $\mathrm{HCl}$ for 12 consecutive days and slaughtered with either a 0- or 3-day withdrawal period. Residues were detected using a rapid on-site screening assay ( $<10-\mathrm{min}$ analysis time), a rapid quantitative ELISA assay ( $<5 \mathrm{hr}$ analysis time), or a laboratory-based quantitative assay (>8 hr). A " + " or "-" indicates a positive or negative result from the rapid immunochromatographic screening assay; a tilde $(\sim)$ indicates difficult scoring of the immunochromatographic screening assay. Data are shown by individual sheep, separated by a comma with a sequential presentation of individual animals consistent across the analytical method.

\begin{tabular}{|c|c|c|c|c|c|}
\hline \multirow{2}{*}{$\begin{array}{l}\text { Zilpaterol } \\
\text { Treatment } \\
\end{array}$} & \multicolumn{5}{|c|}{ Analytical Method } \\
\hline & \multirow[b]{2}{*}{$\mathrm{ICA}^{\mathrm{a}}$} & \multirow{2}{*}{$\begin{array}{l}\mathrm{ELISA}^{\mathrm{b}} \\
n g g^{-1}\end{array}$} & \multirow{2}{*}{$\frac{\text { UPLC-MS/MS }}{n g g^{-1}}$} & \multirow{2}{*}{$\frac{\text { ASAP-MS/MS }}{n g g^{-1}}$} & \multirow{2}{*}{$\frac{\text { ESII-MS/MS }}{n g g^{-1}}$} \\
\hline$\overline{m g ~ k g^{-1} \text { feed }}$ & & & & & \\
\hline \multicolumn{6}{|l|}{-Skeletal muscle- } \\
\hline $\mathrm{L}-0,0.0075$ &,,,---- & $N D^{f}$ & ND & ND & ND \\
\hline $\mathrm{M}-0,0.075$ &,,--- & ND & $>$ LOD & ND & $>\mathrm{LOD}^{\mathrm{g}}$ \\
\hline $\mathrm{H}-0,0.75$ & $\begin{array}{c}\prime \prime \prime \\
\sim,+,+, \sim\end{array}$ & $1.1 \pm 0.0$ & $1.3 \pm 0.1$ & $8.5 \pm 1.8^{h}$ & $1.1 \pm 0.1$ \\
\hline $\mathrm{H}-3,0.75$ &,,,---- & ND & ND & ND & ND \\
\hline \multicolumn{6}{|l|}{$\begin{array}{l}\text {-Liver- } \\
\text {-Liver }\end{array}$} \\
\hline$L-0,0.0075$ &,,,---- & ND & ND & ND & $0.2 \pm 0.1^{g}$ \\
\hline $\mathrm{M}-0,0.075$ &,,--- & ND & $>\mathrm{LOD}$ & $1.9 \pm 0.1^{\mathrm{g}}$ & $0.3 \pm 0.1$ \\
\hline $\mathrm{H}-0,0.75$ &,,,++++ & $1.9 \pm 0.2$ & $3.6 \pm 0.5$ & $4.0 \pm 2.1$ & $3.4 \pm 0.1$ \\
\hline $\mathrm{H}-3,0.75$ &,,--- & ND & ND & ND & $>\mathrm{LOD}^{\mathrm{g}}$ \\
\hline \multicolumn{6}{|l|}{-Kidney- } \\
\hline$L-0,0.0075$ &,,,---- & ND & ND & ND & $>$ LOD \\
\hline$M-0,0.075$ & $-, \sim,-, \sim$ & $0.4 \pm 0.1$ & $>\mathrm{LOD}$ & $0.6 \pm 0.3^{g}$ & $0.4 \pm 0.05$ \\
\hline $\mathrm{H}-0,0.75$ &,,+++ & $2.4 \pm 0.3$ & $4.4 \pm 0.3$ & $2.4 \pm 1.7$ & $4.0 \pm 0.4$ \\
\hline $\mathrm{H}-3,0.75$ &,,,--- & ND & ND & ND & $>$ LOD \\
\hline \multicolumn{6}{|l|}{-Lung- } \\
\hline $\mathrm{L}-0,0.0075$ &,,,---- & ND & ND & ND & $>\operatorname{LOD}^{\mathrm{h}}$ \\
\hline M- $0,0.075$ &,,,---- & ND & $>\mathrm{LOD}$ & ND & $0.3 \pm 0.1$ \\
\hline $\mathrm{H}-0,0.75$ &,,+++ & $1.2 \pm 0.1$ & $2.0 \pm 0.1$ & $1.9 \pm 1.0^{g}$ & $1.8 \pm 0.1$ \\
\hline $\mathrm{H}-3,0.75$ &,,--- & ND & ND & ND & $0.3 \pm 0.2^{h}$ \\
\hline
\end{tabular}

${ }^{a}$ Immunochromatographic assay; muscle LOD, $2.4 \mathrm{ng} \mathrm{g}^{-1}$. LODs for liver, kidney, and lung were not determined.

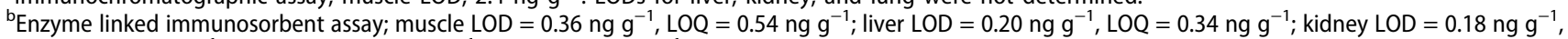
$\mathrm{LOQ}=0.30 \mathrm{ng} \mathrm{g}^{-1}$; lung $\mathrm{LOD}=0.15 \mathrm{ng} \mathrm{g}^{-1}, \mathrm{LOQ}=0.25 \mathrm{ng} \mathrm{g}^{-1}$.

CUltraperformance liquid chromatography-mass spectrometry; muscle LOD $=0.1 \mathrm{ng} \mathrm{g}^{-1}, \mathrm{LOQ}=1.0 \mathrm{ng} \mathrm{g}^{-1}$; liver LOD $=0.20 \mathrm{ng} \mathrm{g}^{-1}, \mathrm{LOQ}=1.0 \mathrm{ng} \mathrm{g}{ }^{-1} ; \mathrm{kidney}^{\mathrm{C}}$ $\mathrm{LOD}=0.2 \mathrm{ng} \mathrm{g}^{-1}, \mathrm{LOQ}=1.0 \mathrm{ng} \mathrm{g}^{-1}$; lung $\mathrm{LOD}=0.2 \mathrm{ng} \mathrm{g}^{-1}, \mathrm{LOQ}=1.0 \mathrm{ng} \mathrm{g}^{-1}$.

${ }^{\mathrm{d}}$ Atmospheric Solid Analysis Probe MS; muscle LOD $=0.2 \mathrm{ng} \mathrm{g}^{-1}$, LOQ $=0.6 \mathrm{ng} \mathrm{g}^{-1}$; liver LOD $=0.3 \mathrm{ng} \mathrm{g}^{-1}$, LOQ $=1.1 \mathrm{ng} \mathrm{g}^{-1}$; kidney LOD $=0.1 \mathrm{ng} \mathrm{g}{ }^{-1}$, LOQ $=0.4 \mathrm{ng} \mathrm{g}^{-1}$; lung LOD $=0.4 \mathrm{ng} \mathrm{g}^{-1}, \mathrm{LOQ}=1.2 \mathrm{ng} \mathrm{g}^{-1}$.

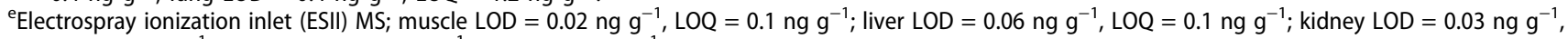
$\mathrm{LOQ}=0.1 \mathrm{ng} \mathrm{g}^{-1}$; lung $\mathrm{LOD}=0.03 \mathrm{ng} \mathrm{g}^{-1}, \mathrm{LOQ}=0.1 \mathrm{ng} \mathrm{g}^{-1}$.

${ }^{\mathrm{f}} \mathrm{ND}$, not detected.

${ }^{9}$ Average of two data points, two sheep were ND.

${ }^{\mathrm{h}}$ Average of three data points, one sheep was ND.

parallel), and by UPLC-MS/MS which can easily extend to over $8 \mathrm{~h}$ depending upon the number of samples run and the degree of processing required. We used the samples processed for UPLC-MS/MS to analyse zilpaterol by ESII-MS/MS and were able to obtain an approximate order of magnitude increase in sensitivity relative to UPLC-MS/MS. A hyphenated mass spectrometric method, ASAP, required minimal sample preparation; tissue samples $(\sim 100 \mathrm{mg})$ prepared for ASAP-MS/MS were extracted with $200 \mu \mathrm{L}$ of ice-cold acetonitrile followed by simple centrifugation (Chakrabarty et al. 2018).

Zilpaterol residues were not detected in any tissues of sheep provided the L-0 treatment by conventional assays such as ICA, ELISA, or UPLC-MS/MS. Emerging mass-spectral based methods including ASAP-MS/MS and ESII-MS /MS were able to detect and/or quantify residues in kidney, liver, and lung from some L-0 animals, with the exception of muscle, with ESII-MS/MS having the greater sensitivity for most tissues (Table 3). Zilpaterol residues were always detectable by ICA screen of liver, kidney, or lung of $\mathrm{H}-0$ animals, but only in one-half of the skeletal muscle samples. In contrast, the use of quantitative ELISA, UPLC-MS/MS, ASAP-MS/MS, and ESIIMS/MS was always useful for detecting and quantifying zilpaterol residues in tissues of H-0 sheep. A 3-d withdrawal period, however, was sufficient to reduce tissue residues in $\mathrm{H}-3$ sheep to nondetectable levels for all methods except ASAPMS/MS and ESII-MS/MS. 


\section{Discussion}

The presence of zilpaterol residues in competitive livestock (HLSR, Houston Livestock Show and Rodeo 2018; NWSS 2018), horses and dogs (ARCI 2018), and humans (WADA 2015, 2018) are strictly banned. Nevertheless, numerous allegations of doping have occurred after urine or tissues of animals (Scheidegger 2013; Bergin 2014; CHRB 2014) have tested positive for zilpaterol. Regardless of the class of animal, allegations of "doping" typically carry severe consequences including possible suspension of animals, fining, and/or banning of trainers or owners from the future competition (ARCI 2018; NWSS 2018). If legal proceedings are initiated, costs for counsel and laboratory analyses are typically borne by the accused (RMTC 2016).

On a much broader scale, the presence of zilpaterol residues (as well as other $\beta$-adrenergic agonists) in commercially produced food animals can have costly trade implications. In the United States, where zilpaterol is approved for use only in cattle, maximum allowable residues levels for zilpaterol in beef muscle and liver are 10 and $12 \mathrm{ng} \mathrm{g}^{-1}$, respectively. Beef tissues produced in the United States, but destined for markets outside the US, must comply with zilpaterol tolerances of the importing country. For example, the Korean MRL for zilpaterol in beef muscle is 1 $\mathrm{ng} \mathrm{g}^{-1}$ and for the beef liver is $5 \mathrm{ng} \mathrm{g}^{-1}$ (MRL Database 2019). Other countries, which strictly ban zilpaterol, do not allow the import of any beef product containing zilpaterol residues. Any detectable zilpaterol residue in non-beef meats, inside or outside the US, is considered violative since zilpaterol is approved only for use in beef animals. Regardless of the presence or absence of tolerance, exporters must ensure that meat animal products comply with the importing countries residue standards.

Sometimes such a guarantee has been problematic. For example, in 2013 South Korea suspended a 22ton lot of beef imported from the US because of the presence of zilpaterol residues and requested that the importer "destroy or send back the meat" (Chung and Waters 2013). The same year Taiwan detected zilpaterol residues in beef imports on at least three occasions (Hung et al. 2013) and suspended imports from some U.S. beef producers. A 2013 Russian ban on imports of U.S. meats because of the presence of $\beta$ agonists was said to have cost the U.S. meat industry $\$ 500$ million in sales (Centner et al. 2014) and, as of 2017, the Chinese government required laboratory reports for each lot of imported meat sampled in addition to conducting residue testing during port inspections (Fields et al. 2018).

Regardless of whether an enforcing agency represents international, national, state, county, or local interests, those accused of causing a residue violation often claim innocence with respect to treating animals with an illicit drug (CHRB 2014; RMTC 2016). Numerous examples exist in which contaminated feeds or foods, rather than illicit activity, was the source of an illegal drug residue (Scheidegger 2013; Bergin 2014; RMTC 2016). Trace level contamination of food with $\beta$-agonists is a problem because exposures to such food can cause positive drug tests in consumers. For example, Guddat et al. (2012) demonstrated that the illicit $\beta$-agonist clenbuterol could be detected in the urine of $79 \%$ of individuals returning from China, even though clenbuterol is banned in China. It was presumed that clenbuterol exposures originated from the consumption of contaminated meat. Horse feed, contaminated with zilpaterol during manufacture, was widely acknowledged to be the source of illegal zilpaterol resides detected in at least 48 positive drug tests (Anonymous 2013; Scheidegger 2013). A more recent example occurred when a horse trainer in Iowa faced a $\$ 10,000$ (US) fine and a year suspension from racing when two horses under his care tested positive for ractopamine. Although the ractopamine levels detected were reported as "very low" and not sufficient to cause a "performance-enhancing effect" the burden of proof of innocence was on the trainer who was responsible for legal and laboratory costs (RMTC 2016). The trainer ultimately proved that contaminated feed was the cause of positive urine and blood tests. Of immediate concern to animal producers, Gressler et al. (2016) demonstrated an average concentration of $36 \mathrm{ng} \mathrm{g}^{-1}$ of ractopamine in Brazilian meat and bone meal, a widely used feed ingredient. When such meat and bone meal was fed to swine, residues were readily detected in urine, but not tissues 
(Aroeira et al. 2019) using a method having an LOQ of 0.2 to $1 \mu \mathrm{g} \mathrm{kg}-1$. Under "zero tolerance" rules any detectable residue, no matter how low a concentration, can be considered prima facie evidence of illicit activity (HLSR 2018), depending upon the regulatory authority. However, it has long been recognized that the presence of trace quantities of the drug within an animal matrix may be irrelevant with respect to conveying physiologic action (Toutain 2010).

For leanness-enhancing $\beta$-agonists such as zilpaterol, threshold doses and minimal lengths of feeding are required for biological activity. For example, dose-response studies have established an optimal zilpaterol $\mathrm{HCl}$ dose for production effects in cattle of $0.17 \mathrm{mg} \mathrm{kg}^{-1}$ body weight and a minimal feeding period of 20 days (Intervet 2006). In sheep and goats, doses of zilpaterol for growth performance are generally realized at $0.1 \mathrm{mg} \mathrm{kg}{ }^{-1}$ body weight (Ríos Rincón et al. 2010; López-Carlos et al. 2014;) and are optimized at $0.15 \mathrm{mg} \mathrm{kg}^{-1}$ body weight or above (EstradaAngulo et al. 2008; Mondagrón et al. 2010; Rodea et al. 2016). Expressed on a dietary concentration basis, zilpaterol is active in sheep at doses between 2.1 and $16.9 \mathrm{mg} \mathrm{kg}^{-1}$ of diet (dry matter basis; Mondragón et al. 2010; López-Carlos et al. 2014). The label dose of zilpaterol is $7.5 \mathrm{mg} \mathrm{kg}^{-1}$ fed to cattle during the last 20 to 40 days on feed; in sheep, zilpaterol may affect several growth or carcass endpoints when fed from 14 to 42 days (López-Carlos et al. 2011).

Animals excrete relatively high concentrations of zilpaterol in urine during times of active exposures at production-enhancing doses. For example, data in Table 4 confirm that urinary concentrations of zilpaterol typically exceed 1,000 $\mathrm{ng} \mathrm{mL} \mathrm{m}^{-1}$ (Stachel et al. 2003; Shelver and Smith 2006) and sometimes exceed $10,000 \mathrm{ng} \mathrm{mL}^{-1}$ in urine from animals during zilpaterol exposure (Shelver and Smith 2011). In the current study, the greatest urinary zilpaterol concentrations were 200 to $400 \mathrm{ng} \mathrm{mL}^{-1}$ during active feeding at zilpaterol concentrations one-tenth the label dose. Further reductions in urinary zilpaterol concentrations, commensurate with dose $\left(1 / 100^{\text {th }}\right.$ and $1 /$ $1000^{\text {th }}$ the label dose), were measured during animal exposures. Based on existing urinary data, one could generally surmise that an animal excret-

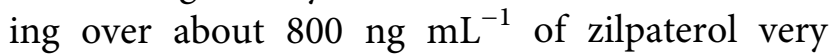
likely received a dose that approached, or was at, a performance-enhancing dose. One might also surmise that animals excreting less than 500 ng $\mathrm{mL}^{-1}$ of zilpaterol are in the withdrawal phase of a growth-enhancing dose or were exposed to a zilpaterol dose below that which causes production effects. Other variables including frequency of feeding, exposure duration, and time of urine collection could influence absolute quantities of zilpaterol excretion, but the order of magnitude of residues collected at a given point will reflect the magnitude of recent exposure.

Reported tissue residue data (Table 4) suggest that animals dosed with production level doses of zilpaterol will have liver or kidney residues above $20 \mathrm{ng} \mathrm{g}^{-1}$ if slaughtered with no withdrawal period. Livers and kidneys of animals dosed with approximately $1 / 10^{\text {th }}$ the label dose and slaughtered with a zero-withdrawal period had residues proportionally lower at 2 to $4 \mathrm{ng} \mathrm{g}^{-1}$ (Table 3). Clearly, if liver or kidney residues are greater than about $20 \mathrm{ng} \mathrm{g}^{-1}$ one can surmise that the animal was exposed to growth-enhancing doses. Conversely, one may surmise that liver or kidney residues below about $10 \mathrm{ng} \mathrm{g}^{-1}$ are from animals that were slaughtered during a withdrawal period or were from animals which were not exposed to a labeled dose. In the United States, zilpaterol is labelled with a required 3-day withdrawal period.

This study clearly demonstrates that numerous detection technologies, whether designed for screening or quantitative purposes, can detect animal exposure to dietary zilpaterol levels far below those required for growth-enhancing effects. Concentrations of zilpaterol in urine or tissues can be used to determine exposures but are less useful for determining whether exposures were purposeful or accidental. The usefulness of residue data to assess guilt or intent with respect to causing growth-enhancing effects is not great unless the magnitude of the residue concentration is clearly sufficient to establish exposure to high levels. In such cases, feed analyses should reveal commensurate levels of zilpaterol. 
Table 4. Zilpaterol residues and excretion in beef, swine, sheep, and horses administered zilpaterol doses documented to have caused production enhancing effects in cattle and sheep.

\begin{tabular}{|c|c|c|c|c|c|c|c|c|}
\hline \multirow[b]{3}{*}{ Species } & \multicolumn{2}{|c|}{ Dose } & \multirow{3}{*}{$\frac{\frac{\text { Withdrawal }}{\text { time }}}{h}$} & \multicolumn{4}{|c|}{ Zilpaterol Residue } & \multirow[b]{3}{*}{ Reference } \\
\hline & Amount & Duration & & Liver & Muscle & Kidney & Urine & \\
\hline & $\overline{m g k g^{-1} b w}$ & $d$ & & $\overline{n g g^{-1}}$ & $\overline{n g g^{-1}}$ & $n g g^{-1}$ & $n g m L^{-1}$ & \\
\hline \multirow[t]{4}{*}{ Cattle } & $\sim 0.15$ & 12 & 12 & $25 \pm 8$ & $4 \pm 2$ & $44 \pm 29$ & & Intervet 2006 \\
\hline & & & 24 & $10 \pm 2$ & $2 \pm 0$ & $11 \pm 1$ & & \\
\hline & & & 48 & $4 \pm 4$ & ND & $5 \pm 5$ & & \\
\hline & & & 96 & ND & ND & ND & & \\
\hline \multirow[t]{12}{*}{ Veal Calf } & 0.15 & 2 & 0 & & & & 1,400 & Van Hoof et al. 2005 \\
\hline & & 3 & 0 & & & & 1,100 & \\
\hline & & 4 & 0 & & & & 2,600 & \\
\hline & & 5 & 0 & & & & 900 & \\
\hline & & 6 & 0 & & & & 1450 & \\
\hline & & 7 & 0 & & & & 1490 & \\
\hline & & 8 & 0 & & & & 900 & \\
\hline & & 9 & 0 & & & & 1050 & \\
\hline & & 10 & 0 & & & & - & \\
\hline & & 11 & 0 & & & & 800 & \\
\hline & & 12 & 0 & & & & 2050 & \\
\hline & & 13 & 0 & & & & 1500 & \\
\hline \multirow[t]{19}{*}{ Cattle } & 0.15 & 1 & & & & & $>1,000$ & Stachel et al. 2003 \\
\hline & & 2 & & & & & $>1,000$ & \\
\hline & & 3 & & & & & $>1,000$ & \\
\hline & & 4 & & & & & $>1,000$ & \\
\hline & & 7 & & & & & $>1,000$ & \\
\hline & & 8 & & & & & $>1,000$ & \\
\hline & & 9 & & & & & $>1,000$ & \\
\hline & & 10 & & & & & $>1,000$ & \\
\hline & & 11 & & & & & $>1,000$ & \\
\hline & & 13 & & & & & $>1,000$ & \\
\hline & & 14 & 0 & & & & $>1,000$ & \\
\hline & & 14 & 24 & 27 & 7 & 44 & $\sim 900$ & \\
\hline & & 14 & 48 & & & & $\sim 500$ & \\
\hline & & 14 & 72 & & & & $\sim 30$ & \\
\hline & & 14 & 96 & & & & $\sim 10$ & \\
\hline & & 14 & 120 & & & & $\sim 7$ & \\
\hline & & 14 & 192 & & & & $\sim 7$ & \\
\hline & & 14 & 216 & & & & $\sim 1$ & \\
\hline & & 14 & 240 & 0.03 & 0.03 & 0.01 & $<1$ & \\
\hline \multirow[t]{4}{*}{ Swine } & 0.15 & 25 & 24 & 8 & 3 & 8 & 189 & Stachel et al. 2003 \\
\hline & & & 48 & 0.5 & 0.2 & ND & 10 & \\
\hline & & & 96 & 0.2 & 0.2 & 0.3 & 6 & \\
\hline & & & 120 & ND & 0.02 & ND & 2 & \\
\hline \multirow[t]{11}{*}{ Sheep } & 0.15 & 1 & 0 & & & & $>1,000$ & Shelver and Smith 2006 \\
\hline & & 3 & 0 & & & & $>1,000$ & \\
\hline & & 5 & 0 & & & & $>1,000$ & \\
\hline & & 8 & 0 & & & & $>1,000$ & \\
\hline & & 10 & 0 & 30.4 & 13.5 & 31.5 & $708 \pm 861$ & \\
\hline & & 10 & 24 & & & & $195 \pm 141$ & \\
\hline & & 10 & 48 & 1.9 & 0.8 & 1.7 & $69 \pm 51$ & \\
\hline & & 10 & 72 & & & & $53 \pm 59$ & \\
\hline & & 10 & 120 & 0.2 & 0.2 & 0.2 & $8 \pm 15$ & \\
\hline & & 10 & 168 & & & & 1 & \\
\hline & & 10 & 216 & 0.1 & - & - & $<1$ & \\
\hline \multirow[t]{7}{*}{ Horse } & 0.17 & 1 & 0 & & & & 10,674 & Shelver and Smith 2011 \\
\hline & & & 1 & & & & 1,338 & \\
\hline & & & 3 & & & & 250 & \\
\hline & & & 5 & & & & 15 & \\
\hline & & & 7 & & & & 5 & \\
\hline & & & 14 & & & & 3 & \\
\hline & & & 21 & & & & 1 & \\
\hline
\end{tabular}

\section{Acknowledgments}

The technical assistance of Madison Berger, Dee Ellig, Grant Herges, Jason Holthusen, Tyler Huff, and Amy McGarvey is gratefully acknowledged.
Mention of trade names or commercial products in this publication is solely for the purpose of providing specific information and does not imply recommendation or endorsement by the U.S. Department of Agriculture. USDA is an equal opportunity provider and employer. 


\section{Disclosure Statement}

No potential conflict of interest was reported by the authors.

\section{ORCID}

David J. Smith (D) http://orcid.org/0000-0001-8883-4744

\section{References}

Anonymous. 2013. Positive zilpaterol tests cleared, feed contamination cited. [Accessed 2019 Apr 4]. https://thehorse. com/115616/positive-zilpaterol-tests-cleared-feedcontamination-cited.

[ARCI] Association of Racing Commissioners International. 2018. Uniform classification guidelines for foreign substances and recommended penalties module rule (v.13.4). [Accessed 2019 Apr 4]. http://arci.blob.core.windows.net/ webdocs/2018_01_09_CLASSIFICATION_V13.4.pdf.

Aroeira CN, Feddern V, Gressler V, Molognoni L, Daguer H, Dalla Costa OA, de Lima GJMM, Contreras-Castillo CJ. 2019. Determination of ractopamine residue in tissues and urine from pig fed meat and bone meal. Food Addit Contam Part A. 36:424-433.

Bergin N 2014. Family sues feed company over lamb's failed drug test. Lincoln Journal Star. [Accessed 2019 Apr 4]. https://journalstar.com/news/state-and-regional/nebraska/ family-sues-feed-company-over-lamb-s-failed-drug-test /article_56ca3dea-cd7a-5a7e-b9bd-16c9a9b7f2c8.html.

Brand TS, Genis MP, Hoffman LC, van de Vyver WFJ, Swart R, Jordaan GF. 2013. The effect of dietary energy and the inclusion of a $\beta$-adrenergic agonist in the diet on the meat quality of feedlot lambs. S Afr J Anim Sci. 43: S140-S145.

Centner TJ, Alvey JC, Stelzleni AM. 2014. Beta agonists in livestock feed: status, health concerns, and international trade. J Anim Sci. 92::4234-4240.

Chakrabarty S, Shelver WL, Hakk H, Smith DJ. 2018. Atmospheric solid analysis probe and modified desorption electrospray ionization mass spectrometry for rapid screening and semi-quantification of zilpaterol in urine and tissues of sheep. J Agric Food Chem. 66:10871-10880.

[CHRB] California Horse Racing Board. 2014. California Horse Racing Board, Case \#14LA0013. [Accessed 2014 Apr 28].

Chung J, Waters T. 2013 Oct 8. South Korea suspends some U.S. beef imports over feed additive. Reuters. [Accessed 2019 Apr 4]. https://www.reuters.com/article/us-beef-usakorea/south-korea-suspends-some-u-s-beef-imports-overfeed-additive-idUSBRE99802620131009.

Estrada-Angulo A, Barreras-Serrano A, Contreras G, Obregon JF, Robles-Estrada JC, Plascencia A, Zinn RA. 2008. Influence of level of zilpaterol chlorhydrate supplementation on growth performance and carcass characteristics of feedlot lambs. Small Rumin Res. 80:107-110.
Fenner MA, Chakrabarty S, Wang B, Pagnotti VS, Hoang K, Trimpin S, McEwen CN. 2017. An LC/MS method providing improved sensitivity: electrospray ionization inlet. Anal Chem. 89:4798-4802.

Fields KH, Therrien DA, Haggard J, Clayton P. 2018. International beef trade: A value proposition. Animal Frontiers. 8:1-21.

Gressler V, Franzen ARL, de Lima GJMM, Tavernari FC, Dalla Costa OA, Feddern V. 2016. Development of a readily applied method to quantify ractopamine residue in meat and bone meal by QuEChERS-LC-MS/MS. J Chrom B. 1015-1016:192-200.

Guddat S, Fußhöller G, Geyer H, Thomas A, Braun H, Haenelt N, Schwenke A, Klose C, Thevis M, Schänzer W. 2012. Clenbuterol - regional food contamination a possible source for inadvertent doping in sports. Drug Test Anal. 4:534-538.

Hatefi A, Towhidi A, Zali A, Zeinoaldini S, Ganjkhanlou M, Plascencia A. 2017. Effects of dietary zilpaterol hydrochloride ( $\beta 2$-agonist) supplementation on finishing castrated male goats: metabolic endocrine, blood constituents, plasma volume, respiratory rate and cardiac changes. J Appl Anim Res. 45:447-453.

[HLSR] Houston Livestock Show and Rodeo. 2018. Houston Livestock Show $^{\mathrm{TM}}$ and residue avoidance. [Accessed 2019 Apr 2]. http://www.rodeohouston.com/Portals/0/Content/ GetInvolved/Exhibitors-Participants/Livestock\%20Show/ HLSR-Drug-Residue.pdf.

Hung F, Thukral N, Pfeiffer T. 2013 Oct 29. Taiwan detects more U. S. beef with banned feed additive. Reuters. [Accessed 2019 Apr 2]. https://www.reuters.com/article/ us-beef-usa-taiwan/taiwan-detects-more-u-s-beef-withbanned-feed-additive-idUSBRE99S0IO20131029.

Intervet. 2006. NADA 141-258, Zilmax (zilpaterol hydrochloride), Type A medicated article for cattle fed in confinement for slaughter. Freedom of information summary. [Accessed 2019 Apr 2]. https://animaldrugsatfda.fda.gov/ adafda/app/search/public/document/downloadFoi/811.

López-Carlos MA, Aguilera-Soto JI, Ramírez RG, Rodríquez H, Carrillo-Muro O, Méndez-Llorente $\mathrm{F}$. 2014. Effect of zilpaterol hydrochloride on the growth performance and carcass characteristics of wether goats. Small Rumin Res. 117:142-150.

López-Carlos MA, Ramírez RG, Aguilera-Soto JI, Aréchiga CF, Méndez-Llorente F, Rodríquez H, Silva JM. 2010. Effect of ractopamine hydrochloride and zilpaterol hydrochloride on growth, diet digestibility, intake and carcass characteristics of feedlot lambs. Livest Sci. 131:23-30.

López-Carlos MA, Ramírez RG, Aguilera-Soto JI, Plascencia A, Rodriguez H, Arechiga CF, Rincon RM, Medina-Flores CA, Gutierrez-Bañuelos H. 2011. Effect of two beta adrenergic agonists and feeding duration on feedlot performance and carcass characteristics of finishing lambs. Livest Sci. 138:251-258.

Macías-Cruz U, Álvarez-Valenzuela FD, Soto-Navarro SA, Águila-Tepato E, Avendaño-Reyes L. 2013. Effect of zilpaterol hydrochloride on feedlot performance, nutrient 
uptake, and digestibility in hair-bred sheep. J Anim Sci. 91:1844-1849.

Merck Animal Health. 2018. Zilmax ${ }^{\circledast}$ Feed Label. [Accessed 2019 Apr 2]. https://www.merck-animal-health-usa.com/ product/cattle/Zilmax/1.

Mondragón J, Domínguez-Vara IA, Pinos-Rodríguez JM, González M, Bórquez JL, Domínguez A, Mejia ML. 2010. Effects of feed supplementation of zilpaterol hydrochloride on growth performance and carcass traits of finishing lambs. Acta Agric Scand A. 60:47-52.

MRL Database. 2019. Veterinary Drugs. [Accessed 2019 Apr 2]. https://bcglobal.bryantchristie.com/db\#pesticides/query.

[NWSS] National Western Livestock Show. 2018. Warning to all junior market livestock exhibitors. If you cheat you will be caught. [Accessed 2019 Apr 2]. http://www.nationalwes tern.com/wp-content/uploads/2014/09/2018-Warning-toall-Juniors.pdf.

Pagnotti VS, Chakrabarty S, Harron AF, McEwen CN. 2012. Increasing the sensitivity of liquid introduction mass spectrometry by combining electrospray ionization and solvent assisted inlet ionization. Anal Chem. 84:6828-6832.

Ríos Rincón FG, Barreras-Serrano A, Estrada-Angulo A, Obregón JF, Plascencia-Jorquera A, Portillo-Loera JJ, Zinn RA. 2010. Effect of level of dietary zilpaterol hydrochloride ( $\beta_{2}$-agonist) on performance, carcass characteristics and visceral organ mass in hairy lambs fed allconcentrate diets. J Appl Anim Res. 38:33-38.

[RMTC] Racing Medication and Testing Consortium. 2016. 'Burden of Proof: iowa trainer proves feed contamination caused ractopamine positives.[Accessed 2019 Apr 2] https://rmtcnet.com/burden-of-proof-iowa-trainer-proves -feed-contamination-caused-ractopamine-positivespaulick-report-8516/.

Rodea AO, Amezcua MB, de la Peña JAP, Ronquillo MG. 2016. Effect of zilpaterol hydrochloride on animal performance and carcass characteristics in sheep: a meta-analysis. J Appl Anim Res. 44:104-112.

Scheidegger J 2013 Mar 27. California horse racing board identifies Purina horse feed contaminated with zilpaterol. DVM360. [Accessed 2019 Apr 2]. http://veterinarynews. dvm360.com/california-horse-racing-board-identifiespurina-horse-feed-contaminated-with-zilpaterol.
Shelver WL, Smith DJ. 2006. Tissue residues and urinary excretion of zilpaterol in sheep treated for 10-days with dietary zilpaterol. J Agric Food Chem. 54:4155-4161.

Shelver WL, Smith DJ. 2011. Immunochemical based zilpaterol measurement and validation in various animal urine and sheep. Food Agric Immunol. 22:247-258.

Shelver WL, Smith DJ. 2018. Development of an immunochromatographic lateral flow assay for the $\beta$-adrenergic agonist feed additive zilpaterol. Food Addit Contam Part A. 35:1519-1529.

Shelver WL, Thorson J, Hammer C, Smith DJ. 2010. Depletion of urinary of zilpaterol residues in horses as measured by ELISA and UPLC-MS/MS. J Agric Food Chem. 58:4077-4083.

Smith DJ. 1998. The pharmacokinetics, metabolism, and residues of $\beta$-adrenergic agonists in livestock. J Anim Sci. 76:173-194.

Smith DJ, Shelver WL, Marx A. 2016. Detection of residues in urine and tissues of sheep treated with trace levels of dietary ractopamine $\mathrm{HCl}$. J Anim Sci. 94:5423-5433.

Stachel CS, Radeck W, Gowik P. 2003. Zilpaterol-a new focus of concern in residue analysis. Anal Chim Acta. 493:63-67.

Toutain P-L. 2010. Veterinary medicines and competition animals: the question of medication versus doping control. In: Cunningham $\mathrm{F}$ et al, editors. Comparative and veterinary pharmacology, handbook of experimental pharmacology 199. Berlin: Springer-Verlag Berlin Heidelberg. p. 315-339.

Van Hoof N, Schilt R, van der Vlis E, Boshuis P, Van Baak M, Draaijer A, De Wasch K, Van de Wiele M, Van Hende J, Courtheyn D, et al. 2005. Detection of zilpaterol $\left(\right.$ Zimax $\left.^{\infty}\right)$ in calf urine and faeces with liquid chromatography-tandem mass spectrometry. Anal Chim Acta. 529:189-197.

[WADA] World Anti-Doping Agency. 2015. The World Anti-Doping Code. [Accessed 2019 Apr 5]. https://www. wada-ama.org/sites/default/files/resources/files/wada2015-world-anti-doping-code.pdf.

[WADA] World Anti-Doping Agency. 2018. The World anti-doping code, prohibited list. [Accessed 2019 Apr 5]. https://www.wada-ama.org/sites/default/files/prohibited_ list_2018_en.pdf. 